\title{
Riparian tree and bird diversity in Cisadane River, South Tangerang City, Indonesia
}

\author{
URFI IZZATI ${ }^{1,2, \varphi}$, HAYATI SARI HASIBUAN ${ }^{1, \bullet \varphi}$ \\ ${ }^{1}$ School of Environmental Science, Universitas Indonesia. Jl. Salemba Raya 4, Jakarta 10430, Indonesia. Tel./fax.: +62-21-31930251, \\ wemail: hayati.hasibuan@ui.ac.id \\ ${ }^{2}$ Environmental and Forestry Education and Training Center of Kadipaten, Ministry of Environment and Forestry. Jl. Raya Timur Sawala, Kotak POS 11, \\ Kadipaten, Majalengka 45452, West Java, Indonesia. Tel./fax. +62-233-661071, `email: urfiizzati@gmail.com
}

Manuscript received: 1 November 2018. Revision accepted: 31 January 2019

\begin{abstract}
Izzati U, Hasibuan HS. 2019. Riparian tree and bird diversity in Cisadane River, South Tangerang City, Indonesia. Biodiversitas 20: 595-603. Riparian is a riverbank area that has unique characteristics. It is a combination of terrestrial with aquatic habitats so that riparian ecosystems have high biodiversity values. Riparian is included in a protected area that is naturally designated for vegetation, but in reality, riparian areas, especially in urban areas, have a lot of conversion of land functions by humans so that it can disrupt diversity of tree and bird species. This study aims to identify the diversity of tree and bird species and the correlation between the two. Riparian length of Cisadane River, South Tangerang City is $20.15 \mathrm{~km}$. The method used was plot line with size of $20 \mathrm{~m} \times 20 \mathrm{~m}$ for tree data and line transect for bird data by systematic sampling with a random start then analyzed using Shannon Wiener index. The results obtained were found 22 tree species included in 11 families with species diversity index $\left(\mathrm{H}^{\prime}\right)$ of 2.707 and 40 bird species belonging to 25 families with species diversity index $\left(\mathrm{H}^{\prime}\right)$ of 2.794 . The diversity of tree and bird species is classified as medium. The results of the analysis using the Pearson correlation between the diversity of tree with bird species obtained that there was no relationship between the two. Based on these results, riparian zones in urban areas need to be maintained and improved in quality so that the diversity of tree and bird species increases so as to create a stable ecosystem.
\end{abstract}

Keywords: Bird, Cisadane, diversity, tree, riparian

\section{INTRODUCTION}

A riparian zone is defined as an interface between land and river or stream (Fu et al. 2016). This zone is usually called river bank. Riparian zones are integral and important components of watersheds throughout the world. While they make up only a small percentage of the total land area, their hydrological and ecological functions must be considered in watershed management (Brooks et al. 2003). One of the ecological functions of riparian zones is to conserve biodiversity (Décamps et al. 2009).

The riparian zones have high value in terms of diversity because they share features with both adjacent upland and aquatic ecosystems (Brooks et al. 2003; Hawes and Smith 2005; Frazier 2006). The riparian zones with its vegetation component is a complex ecosystem that has a vital role in aquatic and terrestrial ecosystem habitats (Hawes and Smith 2005; Clinton 2011). The riparian zone also functions as a corridor that connects separate forests for habitat and movement of terrestrial wildlife (Ramos and Anjos 2014; Miller et al. 2015). Nonetheless, riparian zones have not fared well during the process of urban development (Brooks et al. 2003).

Along with urban development, the pressure of conversion of riparian land in urban areas is getting higher. There has been a decline in riparian vegetation and an increase in built and agricultural land ( $\mathrm{Fu}$ et al. 2016). Changes in riparian land use due to human pressure can disrupt the diversity of flora and fauna (Semiun et al. 2013;
DeCecco and Brittingham 2016). One of the fauna found in riparian ecosystems is birds.

Birds are common fauna in residential areas, such as in urban areas (Endhlicher et al. 2011). Birds are component of the ecosystem that has an important role, including controlling insect populations, helping with pollination of flowers and seed dispersal, as well as helping forest regeneration process, including in urban areas (Hadinoto et al. 2012). Birds are one of the environmental bio-indicators because they have a high sensitivity to environmental changes (Krisanti et al. 2017). The conversion of riparian green areas can reduce the diversity of tree and bird species. The diversity of tree supports the diversity of bird species (Fithri 2012; Ridwan et al. 2015), and there is a positive correlation between the two (Setiawan et al. 2006; Hadinoto et al. 2012, Fadrikal et al. 2015). The older tree stand, the more birds that use the stand (Soendjoto et al. 2018). The more diverse plant species and bird species in an area, the better quality of the environment (Ridwan et al. 2015). Therefore, it is necessary to identify existing conditions of riparian tree and bird species diversity to support riparian management in urban areas that are environmentally and pay attention to urban biodiversity conservation.

South Tangerang City is one of suburban that supported the capital city of Jakarta which has been driven by rapid development due to high urbanization (Winarso 2015). Urbanization is one of the important factors related to urban biodiversity. Urbanization has probably caused the 
local extinction of thousands of species, and many nonnative plants and animals are introduced (Parris 2016). The Cisadane River is the main river of Cisadane watershed. Based on The Directorate General's Strategic Plan for Watershed Control and Protected Forests in 2015-2019, Ministry of Environment and Forestry, The Cisadane watershed is one of 15 watersheds classified as a priority watershed in Indonesia. Therefore, conservation of the riparian ecosystem as one of the important parts of the watershed needs to be considered. Currently, South Tangerang City does not yet have biodiversity data for riparian ecosystem such as the diversity of riparian tree and bird species in Cisadane riparian, even though the availability of such data is needed as a basis to support riparian ecosystem and urban biodiversity conservation. This study aims to identify the diversity of riparian tree and bird species in Cisadane River, South Tangerang City and the correlation between the two. The expected benefits of this research are as a source of information about the diversity of riparian tree and bird species in Cisadane River, South Tangerang City to support conservation of riparian zones and urban biodiversity, as well as the basis for managing riparian zones in urban areas.

\section{MATERIALS AND METHODS}

\section{Study area}

This study was conducted in January until March 2017 with the survey location in the Cisadane River segment of South Tangerang City, Banten Province, Indonesia with a length of $20.15 \mathrm{~km}$ and a riparian width of $30 \mathrm{~m}$ (Figure 1). The area crossed by the Cisadane River in South Tangerang City is the riparian segment of the Setu, Serpong, and North Serpong Rivers.

\section{Procedures}

Tree samplings were done within plot line with size of $20 \mathrm{~m} \times 20 \mathrm{~m}$ as many as 50 plots, following bird transect line with $200 \mathrm{~m}$ inter plot. Trees are woody plants with a stem diameter $>20 \mathrm{~cm}$ (Kusmana 1997). The data recorded were species and number of trees. In supporting analysis data for bird habitat both in the sampling plot and along the transect line tracing, we observed the riparian land uses (agriculture, built-up land, shrubs), another types of vegetation (bamboo, banana, agricultural vegetation), and another fauna exist in the study area.
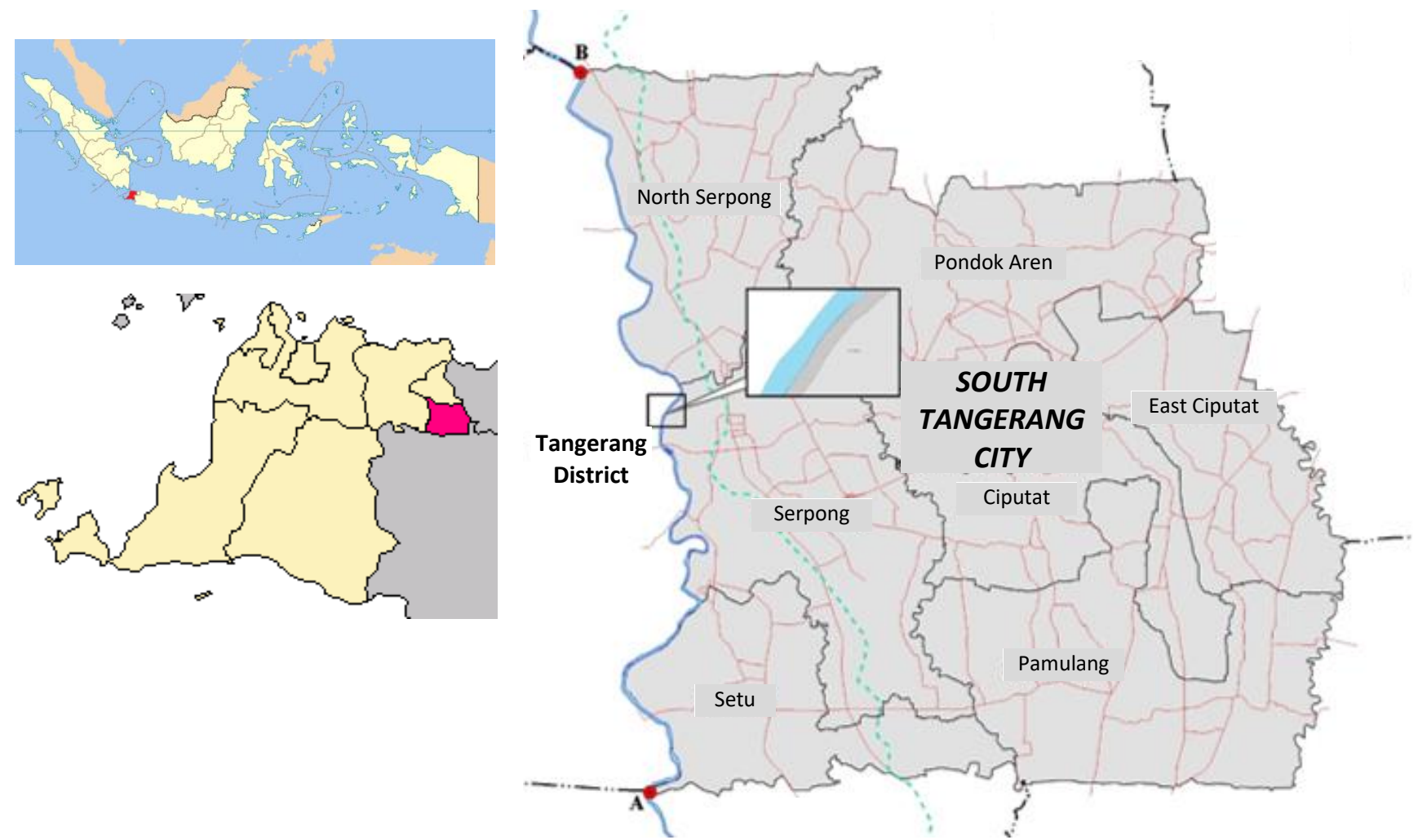

Figure 1. Study area, segment of Cisadane River of South Tangerang City, Banten, Indonesia, along $20.15 \mathrm{~km}$ starting from A point

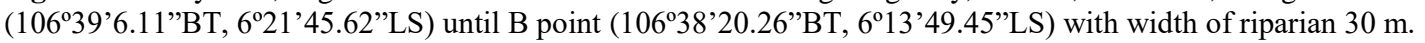


Birds were observed within line transect method with a length of $10 \mathrm{~km}$ (Bibby et al. 2000). Line transect was divided into 10 segments (each segment length is $1 \mathrm{~km}$ ). The transect segments were determined by systematic sampling with random start, by choosing the starting point of line transect segment randomly and then systematically spacing the segment as far as $1000 \mathrm{~m}$. Each transect segment is located in the riparian area which is parallel to river direction. The bird observation was done using the direct watching method and walking continuously on a relatively stable pace which was performed every morning (06.00-10.00) and evening (16.00-18.00). Identification of the birds is only on birds found, not through sound to avoid biased data. The bird data have been recorded to calculate bird diversity is species and number of birds.

\section{Data analysis}

The initial step of the analysis is to categorize the data of trees and birds that have been collected. First categorization based on their conservation status. The conservation of flora and fauna in Indonesia is regulated in the Minister of Environment and Forestry Regulation Number 92 of 2018 concerning Amendment to the Regulation of the Minister of Environment and Forestry Number 20 of 2018 about Protected Flora and Fauna Species. The conservation status of flora and fauna internationally are International Union for Conservation of Nature and Natural Resources (IUCN) Red List of Threatened Species which regulates the threat status and Convention on International Trade in Endangered Species of Wild Fauna and Flora (CITES) Appendices which regulates the trade protection status. The next categorization for bird data is feeding guild that refers to MacKinnon (2010), while tree data is the utility based on literature.

Next step of the analysis is the diversity index. The index calculation was counted by pooling all the data for transects and sampling plots in every riparian segment (Setu, Serpong, and North Serpong) and for South Tangerang City calculation by pooling all the data. Tree and bird species diversity indices were analyzed using the following Shannon Wiener $\left(\mathrm{H}^{\prime}\right)$ index (Magurran 1988) with criteria as in Table 1.

$$
\begin{aligned}
& \mathrm{H}^{\prime}=-\Sigma\{\text { pi ln pi }\} \\
& \text { Where: } \\
& \mathrm{H}^{\prime} \quad: \text { Shannon Wiener Diversity Index } \\
& \text { pi } \quad: \text { Ni/N } \\
& \mathrm{Ni} \quad: \text { number of individual species } \mathrm{i} \\
& \mathrm{N} \quad \text { : total number of individual of all bird species }
\end{aligned}
$$

Table 1. Criteria of Shannon Wiener Index

\begin{tabular}{ll}
\hline H' Value & Category \\
\hline Less than 1.5 & Low \\
$1.5-3.5$ & Medium \\
More than 3.5 & High \\
\hline
\end{tabular}

Correlation analysis between the tree and bird species diversity used Pearson correlation. This analysis tool is used to find the relationship of independent variables $(\mathrm{X})$ with dependent variables (Y), for ratios data (Siregar 2014). This analysis tool was used after normality, linearity, and homoscedasticity tests were carried out. Normality test using Kolmogorov-Smirnov technique with a significance level of 0.05 . The independent variables (X) in this study was the tree species diversity and the dependent variable (Y) was the bird species diversity. The hypothesis of this study was:

Ho: There is no relationship between tree and bird species diversity

Ha: There is relationship between tree and bird species diversity

Significance level used was 0.01 with following formula (Siregar 2014):

$$
r=\frac{n\left(\sum X Y\right)-\left(\sum X \cdot \sum Y\right)}{\sqrt{\left[n \sum X^{2}-\left(\sum X\right)^{2}\right]\left[n \sum Y^{2}-\left(\sum Y\right)^{2}\right]}}
$$

\section{RESULTS AND DISCUSSION}

\section{Tree species diversity}

The results of vegetation analysis in riparian of Cisadane River found 22 species of trees which are included in 11 families (Table 2). Based on its utility, $72.72 \%$ are species that can be used for leaves, fruits, and nectar, while $27.27 \%$ are species that can be used for woods. Some trees found on riparian of Cisadane River are presented in Figure 2.

At sampling sites, other vegetation cover found beside trees are grasses, shrubs, banana plants, bamboo clumps, agricultural land that planted with peanuts, cassava, and rice. This diverse vegetation condition can provide various types of feed for birds such as grains and insects. In addition to vegetation cover, also found the land-built area in this riparian. This condition can interfere with bird existence in this area.

\section{Bird species diversity}

The results of bird analysis found 40 species of birds which are included in 25 families (Table 3). Based on the feeding guild, birds in this area are dominated by insectivorous as many as 16 species (40\%), carnivorous and insectivorous-carnivorous as many as 10 species (25\%), granivorous as many as 7 species (17.5\%), frugivorous-insectivorous are 4 species (10\%), and the remaining 3 species $(7.5 \%)$ are nectarivorous, granivorousfrugivorous, and insectivorous-granivorous. Some birds found on riparian Cisadane River are presented in Figure 3.

\section{The correlation between tree and bird diversity}

Trees in the riparian zone have a function as a provider of bird habitat that is as a provider of feed, shelter, perch, or breeding for birds. The value of diversity of tree and bird species in several locations in the riparian of the Cisadane River in South Tangerang City is presented in Table 4. 
Table 2. List of trees species, individual amount, and utility

\begin{tabular}{|c|c|c|c|c|c|c|c|}
\hline \multirow[b]{2}{*}{ Species } & \multirow[b]{2}{*}{ Local name } & \multirow[b]{2}{*}{ Family } & \multirow[b]{2}{*}{$\begin{array}{c}\text { Ind. } \\
\text { amount }\end{array}$} & \multicolumn{3}{|c|}{ Conservation status } & \multirow[b]{2}{*}{ Utility } \\
\hline & & & & $\begin{array}{c}\text { Permenlhk } \\
92 / 2018 \\
\end{array}$ & IUCN & CITES & \\
\hline Abroma augustum (L.) L.f. & Kapas hantu & Malvaceae & 7 & NP & - & - & Leaf \\
\hline Anthocephaslus cadamba Miq. & Jabon & Rubiaceae & 1 & NP & - & - & Wood \\
\hline Arthocarpus heterophyllus Lam. & Nangka & Moraceae & 4 & NP & - & - & Fruit \\
\hline Artocarpus altilis (Park.) Fosberg & Sukun & Moraceae & 5 & NP & - & - & Fruit \\
\hline Cecropia peltata $\mathrm{L}$. & Ki kopong & Urticaceae & 1 & NP & - & - & Leaf, Wood \\
\hline Ceiba pentandra (L.) Gaertn. & Kapuk randu & Bombacaceae & 3 & $\mathrm{NP}$ & $\mathrm{LC}$ & - & Fruit \\
\hline Dimocarpus longan Lour. & Lengkeng & Sapindaceae & 1 & NP & NT & - & Fruit \\
\hline Dysoxylum gaudichaudianum (Juss.) Miq. & Kedoya & Meliaceae & 6 & NP & - & - & Fruit \\
\hline Enterolobium cyclocarpum (Jacq.) Griseb. & Sengon buto & Fabaceae & 4 & $\mathrm{NP}$ & - & - & Leaf \\
\hline Ficus callosa Willd. & Ilat-ilatan & Moraceae & 2 & NP & - & - & Fruit, Leaf \\
\hline Ficus septica Burm. F. & Awar-awar & Moraceae & 8 & NP & - & - & Fruit, Leaf \\
\hline Leucaena leucocephala (Lam.) de Wit. & Lamtoro & Fabaceae & 7 & $\mathrm{NP}$ & - & - & Wood \\
\hline Mangifera indica $\mathrm{L}$. & Mangga & Anacardiaceae & 5 & NP & DD & - & Fruit \\
\hline Paraserianthes falcataria (L.) Nielsen & Sengon & Fabaceae & 24 & $\mathrm{NP}$ & - & - & Wood \\
\hline Parkia speciosa Hassk. & Petai & Fabaceae & 1 & NP & - & - & Fruit \\
\hline Phyllantus acidus (L.)Skeels & Cermai & Phyllanthaceae & 3 & NP & - & - & Fruit \\
\hline Pterocarpus indicus Willd. & Angsana & Fabaceae & 3 & NP & EN & - & Fruit, Wood \\
\hline Samanea saman (Jacq.) Merr. & Ki hujan & Fabaceae & 4 & NP & - & - & Fruit, Nectar \\
\hline Swietenia mahagoni (L.) Jacq. & Mahoni & Meliaceae & 1 & NP & EN & App. II & Wood \\
\hline Syzygium malaccense (L.) Merr \& Perry & Jambu bol & Myrtaceae & 5 & NP & $\mathrm{LC}$ & - & Fruit \\
\hline Syzygium polyanthum (Wight) Walp. & Salam & Myrtaceae & 1 & NP & - & - & Fruit, Leaf \\
\hline Tectona grandis L.f. & Jati & Verbenaceae & 13 & NP & - & - & Wood \\
\hline
\end{tabular}

Note: Permenlhk $=$ Minister of Environment and Forestry Regulation, NP $=$ non protected, $\mathrm{P}=$ protected, LC $=$ least concern, NT $=$ near threatened, $\mathrm{DD}=$ data deficient, $\mathrm{LC}=$ least concern, $\mathrm{EN}=$ Endangered, App. = Appendix

Based on field observations, there are differences in each riparian segment of Cisadane River. In the Setu segment, the most commonly found land use is shrubs and agricultural land compared to other segments. As for the Serpong segment, trees are found more than the Setu segment, although fewer than the North Serpong segment. While the North Serpong segment which is most commonly found are trees and built-land area compared to other segments.

The correlation between the diversity of tree and bird species in Cisadane River, South Tangerang City is determined by the correlation coefficient. Calculation of correlation with tree species diversity index as $\mathrm{X}$ variable and bird species diversity as $\mathrm{Y}$ variable as follows:

$$
r=\frac{4(23.906)-(8.782)(10.869)}{\sqrt{\left[4(19.697)-\left(8.782^{2}\right)\right]\left[4(29.452)-\left(10.869^{2}\right)\right]}}
$$

$$
\begin{array}{ll}
\text { Where: } & \\
\mathrm{r} & : 0.678 \\
\mathrm{R}^{2} & : 0.460 \\
\text { p-value } & : 0.324 \text { (Sig. } 0.01 \text { ) }
\end{array}
$$

Coefficient of determination $\left(\mathrm{R}^{2}\right)$ which is used to analyze the effect of tree species diversity on bird species diversity in riparian of Cisadane River, South Tangerang City is quite small, only $46 \%$. It means $54 \%$ is determined by other factors. Even the correlation coefficients (r) that used to analyze the direction and strength of relationships between variables is slightly strong, with the ratio 0.678 , the correlation is not significant. This result is supported by the p-value> 0.01 that is equal to 0.324 . The results of the comparison between $\mathrm{p}$-value and $\alpha$, obtained by $\mathrm{p}$-value $=$ $0.324>\alpha=0.01$, so that Ho is accepted, i.e. there is no relationship between diversity of tree species and diversity of bird species.

\section{Discussion}

Tree species diversity

The functions of riparian vegetation include regulating microclimate, providing habitat for animals, stabilizing river cliffs, holding and filtering sediments, and providing organic material (Bongard and Wyatt 2010; NRCS 2011). Riparian vegetation consists of the trees, shrubs, and grasses (Brooks et al. 2003). Trees are vegetation types that have high effectiveness for providing wildlife forest habitat and stabilizing bank erosion compared to vegetation types of grasses and shrubs (Bongard and Wyatt 2010). Trees are a very important habitat for birds, $86 \%$ of birds found in activities in trees (Ridwan et al. 2015), 52.94\% birds used a canopy and sub-canopy strata (Partasasmita et al. 2017). Therefore, the presence of trees in the riparian area is important in carrying out its eco-hydrological function. 
Table 3. List of bird diversity, conservation status, and feeding guild

\begin{tabular}{|c|c|c|c|c|c|c|c|}
\hline \multirow{2}{*}{ Species } & \multirow{2}{*}{ Local name } & \multirow{2}{*}{ Family } & \multirow{2}{*}{$\begin{array}{l}\text { Ind. } \\
\text { amount }\end{array}$} & \multicolumn{3}{|c|}{ Conservation status } & \multirow{2}{*}{$\begin{array}{l}\text { Feeding } \\
\text { Guild }\end{array}$} \\
\hline & & & & Permenlhk 92/2018 & IUCN & CITES & \\
\hline Aegithina tiphia & Cipoh kacat & Aegithinidae & 4 & NP & LC & - & I \\
\hline Amaurornis phoenicurus & Kareo padi & Rallidae & 7 & NP & $\mathrm{LC}$ & - & $\mathrm{C}$ \\
\hline Apus affinis & Kapinis rumah & Apodidae & 2 & NP & $\mathrm{LC}$ & - & I \\
\hline Artamus leucorhynchus & Kekep babi & Artamidae & 23 & NP & $\mathrm{LC}$ & - & I \\
\hline Cacomantis merulinus & Wiwik kelabu & Cuculidae & 4 & NP & $\mathrm{LC}$ & - & I \\
\hline Centropus sinensis & Bubut besar & Cuculidae & 22 & NP & $\mathrm{LC}$ & - & $\mathrm{I}, \mathrm{C}$ \\
\hline Collocalia esculenta & Walet & Apodidae & 144 & NP & $\mathrm{LC}$ & - & I \\
\hline Coturnix Chinensis & Puyuh batu & Phasianidae & 41 & NP & $\mathrm{LC}$ & - & $\mathrm{I}, \mathrm{G}$ \\
\hline Cyornis unicolor & Sikatan biru muda & Muscicapidae & 1 & NP & $\mathrm{LC}$ & - & I \\
\hline Delichon dasypus & Layang-layang rumah & Hirundinidae & 3 & NP & $\mathrm{LC}$ & - & I \\
\hline Dendrocopos moluccensis & Caladi tilik & Picidae & 9 & NP & $\mathrm{LC}$ & - & I \\
\hline Dendrocopus canicapillus & Caladi ulam & Picidae & 2 & NP & $\mathrm{LC}$ & - & I \\
\hline Dicaeum trochileum & Cabai jawa & Dicaeidae & 30 & NP & $\mathrm{LC}$ & - & $\mathrm{G}, \mathrm{F}$ \\
\hline Halcyon cyanoventris & Cekakak jawa & Alcedinidae & 6 & NP & $\mathrm{LC}$ & - & $\mathrm{I}, \mathrm{C}$ \\
\hline Halcyon pileata & Cekakak cina & Alcedinidae & 1 & NP & $\mathrm{LC}$ & - & $\mathrm{I}, \mathrm{C}$ \\
\hline Hirundo striolata & Layang-layang loreng & Hirundinidae & 2 & NP & $\mathrm{LC}$ & - & I \\
\hline Hirundo tahitica & Layang-layang batu & Hirundinidae & 4 & NP & $\mathrm{LC}$ & - & I \\
\hline Ixobrychus cinnamomeus & Bambangan merah & Ardeidae & 1 & NP & $\mathrm{LC}$ & - & $\mathrm{C}$ \\
\hline Lanius schach & Bentet kelabu & Laniidae & 2 & NP & $\mathrm{LC}$ & - & $\mathrm{F}, \mathrm{I}$ \\
\hline Lonchura leucogastroides & Bondol Jawa & Estrildidae & 128 & NP & $\mathrm{LC}$ & - & G \\
\hline Lonchura punctulata & Bondol peking & Estrildidae & 143 & NP & $\mathrm{LC}$ & - & $\mathrm{G}$ \\
\hline Lonchura maja & Bondol haji & Estrildidae & 77 & NP & $\mathrm{LC}$ & - & $\mathrm{G}$ \\
\hline Muscicapa griseisticta & Sikatan sisi gelap & Muscicapidae & 1 & NP & $\mathrm{LC}$ & - & I \\
\hline Nectarina jugularis & Madu sriganti & Nectariniidae & 4 & NP & $\mathrm{LC}$ & - & $\mathrm{N}$ \\
\hline Nycticorax caledonicus & Kowak malam merah & Ardeidae & 1 & $\mathrm{P}$ & $\mathrm{LC}$ & - & $\mathrm{C}$ \\
\hline Nycticorax nycticorax & Kowak malam kelabu & Ardeidae & 3 & NP & $\mathrm{LC}$ & - & $\mathrm{C}$ \\
\hline Oriolus chinensis & Kepudang kuduk hitam & Oriolidae & 1 & NP & $\mathrm{LC}$ & - & $\mathrm{F}, \mathrm{I}$ \\
\hline Orthotomus sepium & Cinenen jawa & Sylviidae & 2 & NP & $\mathrm{LC}$ & - & I \\
\hline Orthotomus sutorius & Cinenen pisang & Sylviidae & 50 & NP & $\mathrm{LC}$ & - & I \\
\hline Otus angelinae & Celepuk jawa & Strigidae & 1 & $\mathrm{P}$ & VU & App. II & $\mathrm{C}$ \\
\hline Passer montanus & Gereja erasia & Passeridae & 77 & NP & $\mathrm{LC}$ & - & G \\
\hline Prinia familiaris & Perenjak jawa & Cisticolidae & 30 & NP & $\mathrm{LC}$ & - & I \\
\hline Psittacula alexandri & Betet biasa & Psittacidae & 5 & $\mathrm{P}$ & NT & App. II & $\mathrm{G}$ \\
\hline Pycnonotus aurigaster & Cucak kutilang & Pycnonotidae & 125 & NP & $\mathrm{LC}$ & - & $\mathrm{F}, \mathrm{I}$ \\
\hline Pycnonotus goiavier & Merbah cerukcuk & Pycnonotidae & 116 & NP & $\mathrm{LC}$ & - & $\mathrm{F}, \mathrm{I}$ \\
\hline Rhipidura javanica & Kipasan belang & Rhipiduridae & 4 & $\mathrm{P}$ & $\mathrm{LC}$ & - & I \\
\hline Streptopelia bitoquata & Dederuk jawa & Columbidae & 2 & NP & $\mathrm{LC}$ & - & G \\
\hline Streptopelia chinensis & Tekukur biasa & Columbidae & 80 & NP & $\mathrm{LC}$ & - & G \\
\hline Todirhamphus chloris & Cekakak sungai & Alcedinidae & 42 & NP & $\mathrm{LC}$ & - & I, C \\
\hline Tringa hypoleucos & Trinil pantai & Scolopacidae & 2 & NP & $\mathrm{LC}$ & - & $\mathrm{I}, \mathrm{C}$ \\
\hline
\end{tabular}

Note: Permenlhk = Minister of Environment and Forestry Regulation, NP = non protected, $\mathrm{P}=$ protected, $\mathrm{LC}=$ least concern, $\mathrm{NT}=$ near threatened, $\mathrm{VU}=$ vulnerable, $\mathrm{I}=$ insectivorous, $\mathrm{G}=$ granivorous, $\mathrm{F}=$ frugivorous, $\mathrm{C}=$ carnivorous, $\mathrm{N}=$ nectarivorous, App. $=$ Appendix

Table 4. Trees and birds diversity index in riparian of Cisadane river South Tangerang City

\begin{tabular}{llcc}
\hline \multirow{2}{*}{ No. } & \multirow{2}{*}{$\begin{array}{l}\text { Riparian segment of } \\
\text { Cisadane River }\end{array}$} & \multicolumn{2}{c}{ Diversity index $\left(\mathbf{H}^{\prime}\right)$} \\
\cline { 3 - 4 } & Setu & 1.903 & Birds \\
\hline 1 & Serpong & 1.938 & 2.700 \\
3 & North Serpong & 2.716 \\
4 & South Tangerang City & 2.707 & 2.660 \\
\hline
\end{tabular}

This study (Table 2) showed that $27.27 \%$ of tree species found which the utility is from its wood. The most common species are Paraserianthes falcataria (L.) Nielsen and Tectona grandis L.f. Both are types of trees whose wood is harvested because of their high economic value. In contrary, the riparian tree species must be a type of tree that can be used for leaves, flowers, seeds, or fruits, not the ones used by the wood. The tree species (Table 2) that suits the riparian zone are from Syzygium sp. and Ficus sp. The Syzygium have an important role in the stabilization of the region along the banks of the river. This is mainly due to the nature and character of roots that can withstand the river flow, as well as hold up or slows down the rate of river flow and prevent erosion of the banks of the river (Mudiana 2016). The Ficus are prominent components of riparian zones where they may also contribute to bank stability and ecologically significant keystone species because they sustain populations of the many seeddispersing animals that feed on their fruits (Pothasin et al. 2014). The existence of trees is a prominent element to support hydrological function.

The existence of trees in riparian must also support the bird habitat. The presence of an animal in a place depends 
on the availability of food sources and suitable habitat conditions (Warsito and Bismark 2009, Lala et al. 2013, Putri 2015). Diversity and richness of bird feed producing vegetation species greatly influence the diversity of bird species (Setiawan et al. 2006, Fithri 2012, Hadinoto et al. 2012, Putri 2015, Ridwan et al. 2015, Saini et al. 2017). The tree species found (Table 2) that can provide feed for birds are Dysoxylum gaudichaudianum (Juss.) Miq., Mangifera indica L., Parkia speciosa Hassk., Pterocarpus indicus Willd., Samanea saman (Jacq.) Merr., Ficus sp. and Syzygium sp. (Putri 2015, Nugroho 2015, Ridwan et al. 2015, Fadrikal et al. 2015). This tree species found is relatively small in number, so it needs to be increased.

The composition of trees affects $90.4 \%$ of the bird species diversity index (Kuswanda 2010). Tree diversity is more important than the size of the area in influencing bird diversity (Fadrikal et al. 2015). The increasing proportion of native tree species and density of large and medium trees could increase the richness of birds (Threfall et al. 2016). Based on comparison between alternative trees for riverbank green open space that refer to Minister of Public Works Regulation Number 5 of 2008 concerning Guidelines for Provision and Utilization of Green Open Space in Urban Areas with native species and suitable in South Tangerang City that refer to Samsoedin and Waryono (2010), other species that can be planted to increase the number of tree species and to invite birds in this riparian area are Spatodea campanulata P. Beauv., Erytrina variegata L., Antidesma bunius (L.) Spreng., Ficus racemosa L., and Sterculia foetida L.

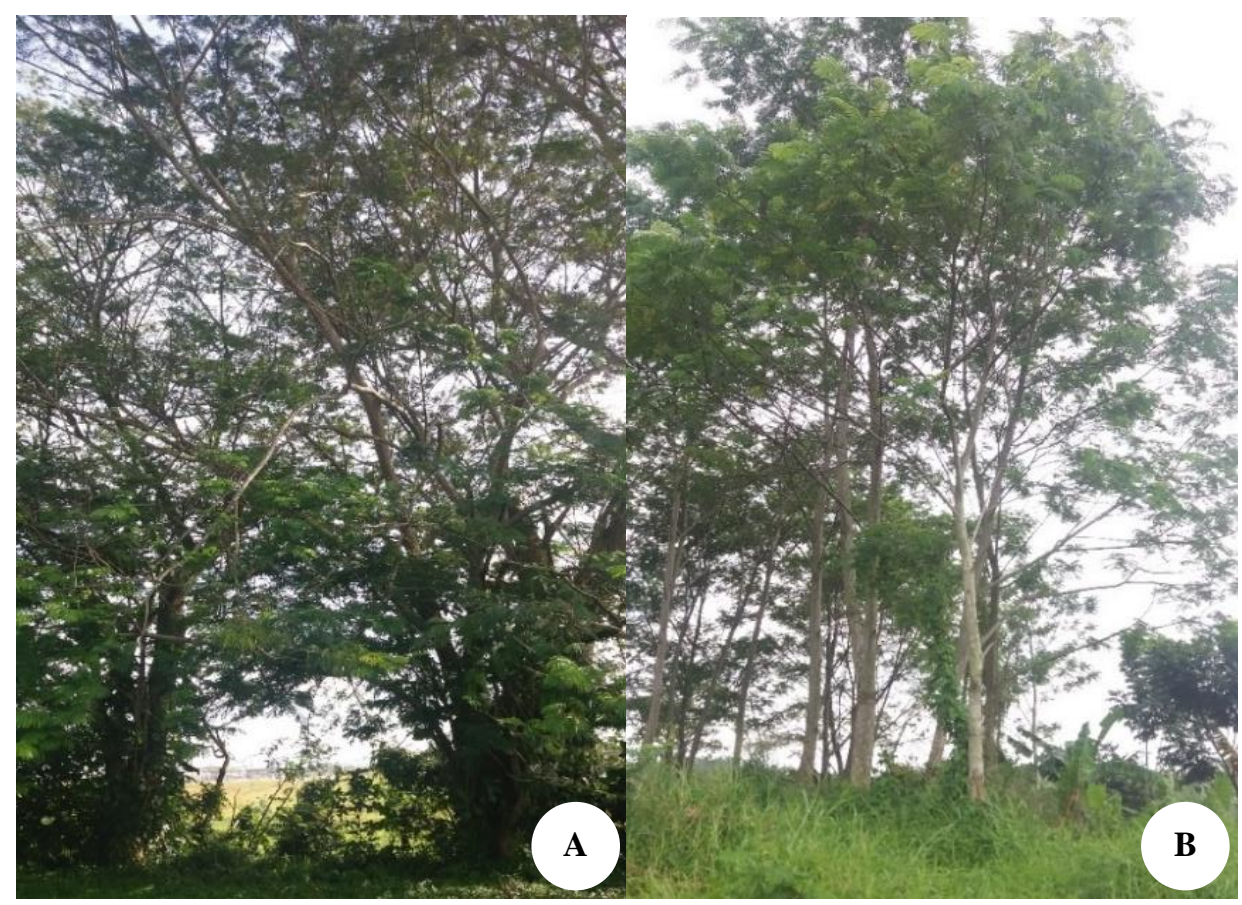

Figure 2.A. Enterolobium cyclocarpum (Jacq.) Griseb., B. Paraserianthes falcataria (L.) Nielsen

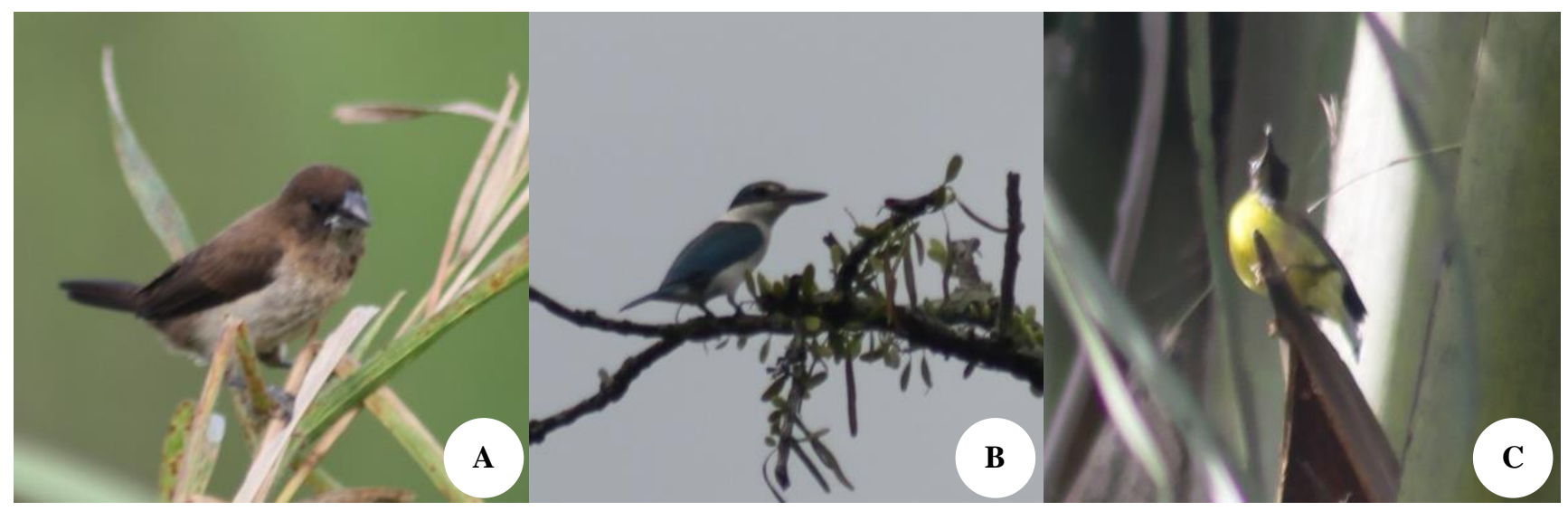

Figure 3. A. Lonchura leucogastroides classified as granivorous, B. Todirhamphus chloris classified as insectivorous-carnivorous, C. Nectarina jugularis classified as nectarivorous. 


\section{Bird species diversity}

The existence of birds in the riparian of Cisadane River, South Tangerang City is still relatively large, with 40 species, even there still $10 \%$ or 4 protected species of birds (nationally and internationally) (Table 3). All four are protected by Minister of Environment and Forestry Regulation Number 92 of 2018 concerning Amendment to the Regulation of the Minister of Environment and Forestry Number 20 of 2018 about Protected Flora and Fauna Species. These birds are Nycticorax caledonicus from Ardeidae family, Psittacula alexandri from Psittacidae family, Rhipidura javanica from Rhipiduridae family, and Otus angelinae from Strigidae family. As for the status of the IUCN, Psittacula alexandri is classified as near threatened and Otus angelinae is classified as a more threatened status, namely vulnerable and according to CITES protection status, the two species are classified as Appendix II, which is a list that is not endangered, but if the trade continues without any regulation, it might turn out to be threatened.

Psittacula alexandri was common in Java and Bali, but now the number is reduced because it is traded for pets, and now only in more remote forest areas, except for large wild colonies around Ragunan zoo (MacKinnon et al. 2010). Otus angelinae, endemic birds in Java, are known from various places in Java, recorded on Mount Salak, Mount Pangrango, Mount Tangkuban Perahu, Mount Ciremai, and the highlands of Ijen (MacKinnon et al. 2010). The discovery of $O$. angelinae in this riparian is a good indication, that the Cisadane riparian function as an animal corridor is still relatively good. MacKinnon et al. (2010) stated that recently $O$. angelinae was only found in Gede Pangrango and Halimun Salak National Park. Gede Pangrango National Park is located in the upstream of Cisadane watershed. So, this condition showed that this riparian serves as a corridor for bird movement between upstream and downstream. The many protected species found on the riparian of the Cisadane River located in urban areas also indicate that this riparian zone has high conservation value. This riparian zone is also still able to provide habitat for other animals, which is indicated by the discovery of weasels (order of Carnivora) and squirrels (order of Scandentia) during field observations. There are many animal species that permanently colonize riparian wetlands, especially anurans, snakes, turtles, raccoons, otters, and many smaller mammals, like muskrats, voles, and shrews (Wantzen and Junk 2008). Therefore it must be maintained and needs to be considered during the urban development process.

This study (Table 3) found that the most dominant is insectivorous birds (40\%). This showed that the insects in riparian are abundant. The insects can be found at trees, shrubs, grasses, or rice field. Insects that are most preferred by insectivorous bird are found in leaves of rice, grasses, legumes, acacia, and teak (Lala et al. 2013). Further stated that insectivorous birds are generally found on the strata between shrubs and trees. The second most dominant is carnivorous and insectivorous-carnivorous bird (25\%). This bird species showed the uniqueness of riparian habitat because this bird species will rarely be found in habitats that do not have water areas. The carnivorous birds found in wetlands by Nababan et al. (2015), but not found in the urban forest by Endah and Partasasmita (2015) are Ixobrychus cinnamomeus, Todirhamphus chloris, Amaurornis phoenicurus, and Nycticorax caledonicus. Other bird species found are granivorous, frugivorous, and nectarivorous birds which are less numerous than insectivorous and carnivorous. The granivorous bird can find its feed in rice fields and grasses, while frugivorous and nectarivorous birds can obtain feed from trees.

\section{The correlation between tree and bird diversity}

The coefficient of determination $\left(\mathrm{R}^{2}\right)$ from the results of correlation analysis between tree and bird species diversity in riparian of Cisadane River showed that $46 \%$ of the tree species diversity affects the bird species diversity on the riparian. It means $54 \%$ of the riparian bird species diversity is influenced by other factors. In the North Serpong segment, the tree diversity index value is highest, but the bird index is the smallest. This is because most of the builtup land found in this segment. The existence of this builtup land can disrupt the existence of birds. McClure et al. (2015) stated that species richness was negatively related to the amount of surface within $100 \mathrm{~m}$ of a survey with richness declining by more than two species for every hectare of paved surface. As for the Setu segment, even though the tree diversity index is the smallest, the bird diversity index is also classified as medium. This condition is caused by a large amount of agricultural land and shrubs found in this segment which is also still able to provide feed for birds. The existence of understorey also influenced bird species diversity (Threlfall et al. 2016). Based on field observation in Cisadane riparian, the various riparian land uses in in this area consist of agriculture, rice fields, grasses, and shrubs. Those various land uses can provide various kinds of food for birds such as grains and insects. In addition, the presence of river water can also affect the availability of other feed such as fish, water insect, frogs, and mollusca. Many birds profit by the rich food offered from the aquatic habitats (Wantzen and Junk 2008). This kind of feed is for carnivorous birds. Riparian habitat is a unique habitat, it is the meeting between terrestrial and aquatic habitats so that bird species diversity is not only affected by trees but other land uses and also river waters. This study showed that the availability of bird feed is influenced by the riparian land use and river water bodies.

Based on the results of correlation analysis, the tree and bird species diversity in the riparian of Cisadane River slightly strong but not significant, so there was no correlation between the two. This result is different from Setiawan et al. (2006) and Hadinoto et al. (2012). This is because the bird species found not only those that get food from trees (frugivorous, nectarivorous, insectivorous) but also found carnivorous species that eat fish, water insects, frogs, small snakes, small mice, mollusca. Insects are not only found in trees, but can also be found in shrubs, rice field, and grasses. The relationship of birds to feeding guild on the Cisadane River in South Tangerang City, based on interaction cycle analysis between birds and feeds availability that found in this study, is illustrated by food web as in Figure 4. 


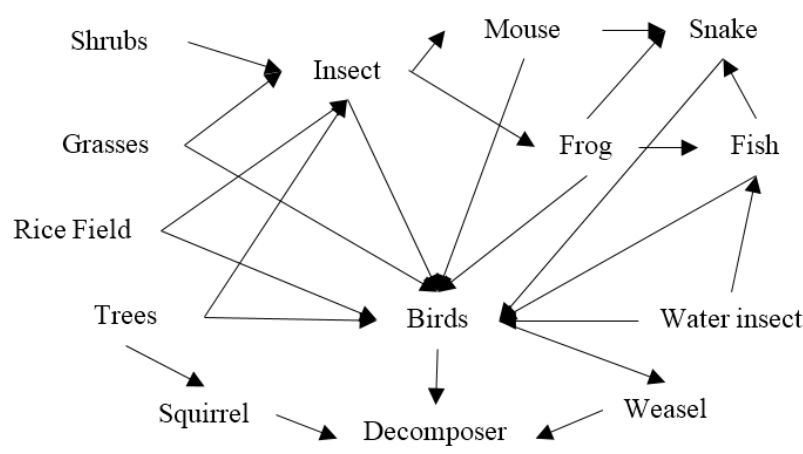

Figure 4. Food web in riparian of Cisadane River, South Tangerang City, Banten Province, Indonesia

Birds found on the riparian of Cisadane River have many alternative feed sources when viewed from existing food webs (Figure 4). The bird composition with feed source other than trees is relatively large, $40 \%$ insectivorous and $25 \%$ carnivorous and carnivorousinsectivorous. Based on Figure 4 the insects for insectivorous birds not only could be found in trees but also could be obtain from other riparian land use (shrubs, grasses, rice field), while feed for carnivorous birds obtained from river water such as fish, mouse (order of Rodentia), frogs (order of Anura), water insects (order of Hemiptera), and snakes (order of Squamata). This abundant availability of food causes many insectivorous and carnivorous birds to be found in this riparian. An increase in frugivorous and nectarivorous birds are needed because it is found in relatively small amounts. This increase in the number of this bird species can be done by planting birdproducing trees. The availability of feed greatly influences the presence (number of individuals and number of species) of frugivorous and nectarivorous birds (Putri 2015).

Planting trees with various species and strata in the riparian area of Cisadane River in South Tangerang City is one of vegetative riparian restoration. Riparian areas are naturally reserved for vegetation for river and watershed protection. Riparian and river flow from upstream to downstream are integral watershed ecosystems. Decreasing quality of riparian vegetation can disrupt riparian ecosystems, including birds and watershed eco-drainage as a whole. Therefore, even though a small part of the watershed, the ecological and hydrological functions of this riparian vegetation are important to be considered in watershed management. This riparian vegetation restoration is needed to maintain the existence of vegetation on the riparian and its eco-hydrological function.

The conclusion of this study is the diversity of tree and bird species in riparian of the Cisadane River, South Tangerang City is classified as medium. The results of the correlation analysis obtained that there was no relationship between the two. Birds found have complex food webs. The birds are not only dependent on trees but also on other riparian land uses and river waters. The availability of bird feed in riparian is unique, a combination of terrestrial and aquatic habitat. However, the presence of trees in riparian rivers is a necessity to support riparian eco-hydrological functions. Therefore, the condition of trees and other vegetation riparian in the Cisadane River, South Tangerang City must be maintained to support urban biodiversity conservation and need to be improved to increase the stability of riparian ecosystems.

\section{ACKNOWLEDGEMENTS}

The author would like to thank the School of Environmental Science, Universitas Indonesia, Jakarta that have funded this publication of research. We also thanks to the Ministry of Environment and Forestry from supporting this research. And to South Tangerang City Environmental Service which has given permission to conduct research on the Cisadane River in South Tangerang City, Indonesia.

\section{REFERENCES}

Bibby C, Jones M, Marsden S. 2000. Field Expedition Techniques: Bird Survey. Birdlife International-Indonesia Programme, Bogor, Indonesia. [Indonesian]

Bongard P, Wyatt G. 2010. Riparian forest buffers for trout habitat improvement: Design of riparian forest buffers (Pamplet). University of Minessota, Minessota.

Brooks KN, Ffolliott PF, Gregersen HM, DeBano LF. 2003. Hydrology and the Management of Watershed $3^{\text {rd }}$ Edition. Blackwell Publishing, Iowa.

Clinton BD. 2011. Stream water responses to timber harvest: Riparian buffer width effectiveness. For Ecol Manag 261: 979-988.

Décamps H, Naiman RJ, McClain ME. 2009. Riparian Zones. Elsivier Inc.

DeCecco JA, Brittingham MC. 2016. Pennsylvanis Wildlife: Riparian Buffers for Wildlife. The Pennsylvania State University, Pennsylvania.

Endah GP, Partasasmita R. 2015. Bird diversity in Bandung City Park, West Java. Pros Sem Nas Masy Biodiv Indon 1 (6): 1289-1294. [Indonesian]

Fadrikal R, Fadliah E, Nugroho J. 2015. Urban bird community: The effect of size area and plant species on bird diversity. Pros Sem Nas Masy Biodiv Indon 1 (8):1842-1846. [Indonesian]

Fithri A. 2012. Bird species of Hutan Kota BNI Banda Aceh, Indonesia. The Proceedings of the $2^{\text {nd }}$ Annual International Conference Syiah Kuala University 2012 \& The $8^{\text {th }}$ IMT-GT Uninet Bioscience Conference. Banda Aceh, 22-24 November 2012.

Frazier H. 2006. Guide to Native and Invasive Streamside Plants: Restoring Riparian Habitats in Ventura County \& along the Santa Clara River in Los Angeles. Ventura County Planning Division, Los Angeles.

Fu B, Li Y, Wang Y, Zhang B, Yin S, Zhu H, Xing Z. 2016. Evaluation of ecosystem service value of riparian zone using land use data from 1986 to 2012. Ecol Indic 69: 873-881.

Hadinoto, Mulyadi A, Siregar YI. 2012. Diversity of bird in urban forest of Pekanbaru, Riau. Jurnal Ilmu Lingkungan 6 (1): 25-42. [Indonesian]

Hawes E, Smith M. 2005. Riparian Buffer Zones: Functions and Recommended Widths. Yale School of Forestry and Environmental Studies.

Krisanti AA, Choirunnafi A, Septiana NO, Pratama FW, Amelia F, Manjaswari A, Septiningtyas PA, Wati AS, Satria JY, Ani IL, Wibowo T, Sugiyarto. 2017. The diversity of diurnal bird species on western slope of Mount Lawu, Java, Indonesia. Biodiversitas 18 (3): 1077-1083.

Kusmana C. 1997. Vegetation Survey Method. PT Penerbit Institut Pertanian Bogor, Bogor, Indonesia. [Indonesian]

Kuswanda W. 2010. Effect of Plant Composition on Bird Population in Batang Gadis National Park, North Sumatra. Jurnal Penelitian Hutan dan Konservasi Alam 7 (2):193-213. [Indonesian] 
MacKinnon J, Phillipps K, Balen B vas. 2010. Birds in Sumatra, Java, Bali and Kalimantan (Including Sabah, Sarawak and Brune Darussalam). Burung Indonesia, Bogor. [Indonesian]

Magurran AE. 1988. Ecologycal Diversity and Its Measurement. Princeton University Press, New Jersey.

McClure CJW, Korte AC, Heath JA, Barber JR. 2015. Pavement and riparian forest shape the bird community along an urban river corridor. Globl Ecology Conserv 4: 291-310.

Miller RW, Hauer RJ, Werner LP. 2015. Urban Forestry: Planning and Managing Urban Greenspaces $3^{\text {rd }}$ ed. Waveland Inc., Illinois.

Mudiana D. 2016. Syzygium diversity in Gunung Baung, East Java, Indonesia. Biodiversitas 17 (2): 733-740.

Nababan BRR, Setiawan A, Nurcahyani N. 2015. Wetland Birds Diversity at Way Pegadungan Rajawali Village Bandar Surabaya District Central Lampung Regency. Jurnal Sylva Lestari 3 (1):71-80. [Indonesian]

NRCS. 2011. Plants for riparian buffers. Natural Resources Conservation Services, Abardeen.

Parris KM. 2016. Ecology of Urban Environments. Wiley Blackwell

Pothasin P, Compton SG, Wangpakapattanawong P. 2014. Riparian Ficus tree communities: The distribution and abundance of riparian fig trees in Northern Thailand. Plos One 9 (10): 1-10.

Putri IASLP. 2015. The importance of feed plant species richness on the diversity of herbivorous bird at Bantimurung Bulusaraung National Park, South Sulawesi. Pros Sem Nas Masy Biodiv Indon 1 (3): 607 614. [Indonesian]

Ramos CC de O, Anjos L dos. 2014. The width and biotic integrity of riparian forest affect richness, abundance, and composition of bird communities. Nat Conservacao 12 (1): 59-64.

Ridwan M, Choirunnafi A, Sugiyarto, Suseno WA, Putri RDA. 2015. The relationship between bird diversity and tree species composition on Kentingan campus Sebelas Maret University Surakarta, Central Java. Pros Sem Nas Masy Biodiv Indon 1 (3): 660-666. [Indonesian]
Saini V, Joshi K, Bhatt K, Singh A, Joshi R. 2017. Short Communication: Waterbird species distribution between natural and manmade wetland in Himalayan foothills of Uttarakhand, India. Biodiversitas 18 (1): 334-340.

Samsoedin I, Waryono T. 2010. Urban Forest and Tree Diversity in Jabodetabek. Yayasan KEHATI-Indonesia Biodiversity Foundation, Jakarta, Indonesia. [Indonesian]

Semiun CG, Arisoesilaningsih E, Retnaningdyah C. 2013. Degradation of Riparian Tree Diversity on Spring Fed Drains and Its Impacts to Water Quality, East Java. J Tropical Life Sci 3 (2): 120-126.

Setiawan A, Alikodra HS, Gunawan A, Darnaedi D. 2006. Tree and Bird Species Diversity in Several Urban Forest Area of Bandar Lampung City. Jurnal Manajemen Hutan Tropika 12 (1): 1-13. [Indonesian]

Siregar S. 2014. Parametric Statistic for Quantitative Research. Bumi Aksara, Jakarta, Indonesia. [Indonesian]

Soendjoto MA, Riefani MK, Triwibowo D, Metasari D. 2018. Birds observed during the monitoring period of 2013-2017 in the revegetation area of ex-coal mining sites in South Kalimantan, Indonesia. Biodiversitas 19 (1): 323-329.

Threlfall CG, Williams NSG, Hahs AK, Livesley SJ. 2016. Approaches to Urban Vegetation Management and the Impacts on Urban Bird and Bat Assemblages. Landsc Urban Plan 153: 28-39.

Wantzen KM, Junk WJ. 2008. Riparian Wetlands. Elsevier B.V., Amsterdam.

Warsito H, Bismark M. 2009. Distribution and population of Parrots on some habitat yypes in Papua. Jurnal Penelitian Hutan dan Konservasi Alam 7 (1): 93-102. [Indonesian]

Waryono T. 2001. Roles and Functions of Bio-eco-Hydrological Services Community of River Basin. Proceedings of National Seminary on Java Integrated Watershed Management, June 2001. Ministry of Forestry, Jakarta, Indonesia. [Indonesian]

Winarso H, Hudalah H, Firman T. 2015. Peri-urban transformation in the Jakarta Metropolitan Area. Habitat International 49: 221-229. 